\title{
Multidirectional effects of triterpene saponins on cancer cells mini-review of in vitro studies
}

\author{
Paulina Koczurkiewicz',2区, Jarosław Czyż¹, Irma Podolak33, Katarzyna Wójcik ${ }^{1,2}$, \\ Agnieszka Galanty ${ }^{3}$, Zbigniew Janeczko ${ }^{3}$ and Marta Michalik1
}

'Department of Cell Biology, Faculty of Biochemistry, Biophysics and Biotechnology, Jagiellonian University, Kraków, Poland; 2Department of Pharmaceutical Biochemistry, Faculty of Pharmacy, Jagiellonian University Medical College, Kraków, Poland; ${ }^{3}$ Department of Pharmacognosy, Faculty of Pharmacy, Jagiellonian University Medical College, Kraków, Poland

Triterpene saponins (saponosides) are found in a variety of higher plants and display a wide range of pharmacological activities, including expectorant, anti-inflamatory, vasoprotective, gastroprotective and antimicrobial properties. Recently, a potential anticancer activity of saponins has been suggested by their cytotoxic, cytostatic, pro-apoptotic and anti-invasive effects. At high concentrations (more than $100 \mu \mathrm{M}$ ) saponins exert cytotoxic and haemolytic effects via permeabilization of the cell membranes. Noteworthy, the inhibition of cancer cell proliferation, the induction of apoptosis and attenuation of cell invasiveness is observed in the presence of low saponin concentrations. Saponins might affect the expression of genes associated with malignancy. These alterations are directly related to the invasive phenotype of cancer cells and depend on "cellular context". It illustrates the relationships between the action of saponins, and the momentary genomic/proteomic status of cancer cells. Here, we discuss the hallmarks of anti-cancer activity of saponins with the particular emphasis on anti-invasive effect of diverse groups of saponins that have been investigated in relation to tumor therapy.

Key words: triterpene saponins, cancer cells, invasiveness, apoptosis, proliferation

Received: 26 May, 2015; revised: 21 June, 2015; accepted: 17 July, 2015; available on-line: 26 August, 2015

\section{INTRODUCTION}

Cancer disease imposes a global threat to public health. Epidemiological data clearly show a year-to-year increase of cancer prevalence throughout the world. In addition to genetic factors that are crucial for cancer formation and development, environmental factors are important for its promotion and progression. These include lifestyle (tobacco, alcohol, physical activity), industry and microbial factors (radiation, pollution, infection) and diet (Ruiz \& Hernandez, 2014). It has been clearly pointed in many reports that improper diet, smoking or a lack of physical activity are factors contributing to the development of cancer (Schwingshlack et al., 2015). That is perhaps why the people living in developed countries are more likely to collapse on the prostate and colon cancer than people from less developed regions (Baade et al., 2009). Even though the forecasts regarding the efficiency of cancer treatment are increasingly optimistic, still there is a pressure to search for new anticancer strategies and drugs that would selectively target cancer cells without imposing the side effects.
Due to the increasing attention paid to the cancer prevention, the term "chemoprevention" has made a career in scientific community (Steward \& Brown, 2013). Some edible plants have been shown to reduce the risk of various types of cancer in humans (Ting et al., 2014). Epidemiological data suggest that the risk of cancer rates are lower in the populations consuming the products largely of "natural" origin (unprocessed) (Saxe et al., 2009). Therefore, a plurality of vegetable substances was examined for chemopreventive properties. Numerous laboratory-based studies have ascribed this activity to the anticancer properties of phytochemicals, which compel tumor cells to arrest their proliferation and/or commit suicide, and lead to the inhibition of experimentally-induced tumor formation in laboratory conditions. Secondary metabolites existing in plants can influence cancer cells through the modulation of intracellular signaling pathways associated with the oxidative stress, inflammation, cell proliferation, apoptosis, angiogenesis and invasion (Bishayee et al., 2011; Bommareddy et al., 2013). These include genistein, apigenin, quercetin, lycopene, resveratrol, curcumin, epigallocatechin gallate, isoflavones and saponins (Wang et al., 2014).

Saponins are secondary metabolites that belong to a diverse group of compounds with high chemoprevention potential. It has been proven that saponins are characterized by a wide spectrum of anti-tumor activity: they can inhibit proliferation and induce the apoptosis of tumor cells, reduce their invasive activity; many of them also exhibit anti-inflammatory and cytoprotective effects on normal cells. In recent years, interest in triterpene saponins and their effects on tumor cells increased. Many authors describe the effects of newly isolated compounds in the context of tumor cells of different type and origin. It is worth noting that triterpene saponins exhibit selectivity of their action on tumor and normal cells of the body, also posses high efficiency in inhibition of carcinogenesis and they can act in comprehensive manner, which allow them to interfere with the carcinogenesis process in several steps. Particularly important area of research on this topic concerns identification of the

e-mail: paulina.koczurkiewicz@uj.edu.pl

*A preliminary report on the same subject was presented at the XLII Winter School "From Genome to Proteome" organized by Faculty of Biochemistry, Biophysics and Biotechnology, Jagiellonian University, 10-14 February, 2015, Zakopane, Poland.

Abbreviations: APAF, Apoptosis Protease Activating Factor; $\mathrm{BCl}-2, \mathrm{~B}$ cell lymphoma-2; CDK2, cyclin dependent kinase; MAPK, mitogen activated protein kinases; MMP-2, matrix metalloproteinases; SAR, structure-activity relationship; TNF-a, tumor necrosis factor type a. 
impact of structural modifications of saponins on their antitumor activity ( $\mathrm{Mu}$ et al., 2013). The effect of these modifications on the bioavailability and bioaccessibility of saponins is yet another attractive research direction (Musende et al., 2009).

Cancer treatment strategies generally are based on inhibition of certain molecular processes that occur in cancer cells. Despite the great diversity of types of cancer, some characteristics of the molecular processes are common to all. Hanahan and Weinberg suggest that most if not all cancer cells have acquired the same set of functional capabilities during their development, albeit through various mechanistic strategies including: insensitivity to anti-growth signals, evading apoptosis, tissue invasion and metastasis (Hanahan \& Wienberg, 2000; Hanahan \& Wienberg, 2011). In the literature, we can find a lot of data about the impact of saponins on tumor cells (Man et al., 2010; Podolak et al., 2010). The main aim of present review was to show the multidirectional effects of saponins on various processes related to the promotion and progression of cancer, taking into account the main assumptions related to hallamarks of cancer with particular emphasis on the papers from recent years (2010-2015).

\section{STRUCTURE, OCCURRENCE AND PROPERTIES OF TRITERPENOID SAPONINS}

Whereas saponins have been detected in animals, such as sea cucumbers and starfish (Thao et al., 2014), higher plants that belong to the class of dicotyledonous (Dicotyledones) are the richest source of triterpene saponins (saponosides). Triterpene saponins are abundant in Primulaceae, Araliaceae, Caryophyllaceae and Hippocastanaceae. In contrast, steroid saponins are characteristic of the monocots class (Monocotyledones). In a few cases, the two types of saponin occur in one plant. An example is Avena sp. (Poaceae) (Osbourn, 2003). Regardless their structure, the highest content of saponins was found in the roots, tubers, leaves and seeds of these plants (Man et al., 2010). In addition, it was observed that the immature plants are characterized by higher saponin content than the more mature representatives of the same species (Francis et al., 2002).

Large amounts of triterpenoid saponins are also found in plants commonly used in everyday diet. The richest diet source of saponins are soybeans, beans, broad beans, lentils, peas, as well as tea and spinach. Many saponins - rich plants have an established position in phytotherapy. The most significant are: licorice smooth, soapwort, horse chestnut, sunflower and ginseng. Other plants rich in saponins, which should be mentioned because of the health benefits, are cowslips (Primula officinalis) which contain prymulasaponins and ivy (Hedera helix) rich in hederasaponins (Holzinger \& Chenot, 2011). The compounds present in both plants possess spasmolytic, expectorant and antifungal properties. Escin is a very popular triterpene saponin occurring in horse chestnut (Aesculus hippocastanum). It has capillary-sealing properties and is a component of medicinal preparations available in the pharmaceutical market for the patients with chronic venous insufficiency (Cesarone et al., 2001). Glycyrrhizin is a saponin present in licorice (Glycyrrbiza glabra). It exhibits potent anti-inflammatory activity and is commonly used in the treatment of ulcers of the stomach and duodenum (Asha et al., 2013; Wei et al., 2014). An example of a plant with long-lived tradition in medicine is ginseng (Panax ginseng). Saponins isolated from ginseng are called panaksosides or ginsenosides (Yang et al., 2014). They possess psychostimulant activity and are commonly used in the geriatric treatment. Notably, in recent years, ginsenosides have been tested in the antitumor properties using a versatile in vitro and in vivo models (Liu et al., 2000).

Chemically, triterpene saponins are glycosides of triterpenes. They consist of polar glycone part (sugar) and non-sugar non-polar components, referred to as the aglycone or sapogenin. The two parts of the molecule are mostly connected to each other by an ether bond. Aglycones are mostly built of pentacyclic, carbon rings. The sugar moieties comprise 1-3 straight or branched chains formed of monosaccharides, of which the most common are: D-glucose, D-galactose, L-rhamnose, L-arabinose, D-xylose, L-fucose and fatty acids: D-glucuronic acid and D-galacturonic acid. Noteworthy, minor structural changes in molecules may stand for major differences in the activity of these compounds. The vast structural diversity of triterpenoid saponins, as well as many interesting biological and pharmacological properties of these compounds makes them the attractive targets for researchers. However, the mechanism(s) of triterpenoid saponins effect on the cellular level are still not clear. Exponential growth of the newly isolated saponosides numbers and their effects on cell lines of various types and origin is not accompanied by identification of mechanisms of their action (Xu et al., 2014b). Only recently, was the research on the role of subtle differences in the saponins structure in determination of compound activity intensified (Böttger et al., 2013; Abbruscato et al., 2014; Xu et al., 2014a) and biodistribution in the body (Musende et al., 2009; Musende et al., 2012).

\section{BIOLOGICAL ACTIVITY OF TRITERPENE SAPONINS}

As mentioned above, triterpene saponins have a wide spectrum of pharmacological activities. Among them, their ability to interact with biological membranes has long been addressed. It can result in a short-term cell membrane rearrangements or its complete destruction. Through the ability to form pores in the membrane, saponins may disrupt the ionic balance of the cells, ultimately leading to the cell lysis and death. It is responsible for the cytotoxic and hemolytic activity of saponosides that is relatively well-described in the literature (Lorent et al., 2014). The pore formation is ascribed to an interaction between saponins and membrane bound cholesterol. The amount of the cholesterol in the membrane has been shown to be important for this interaction. On the other hand, it was also demonstrated that pore formation by saponins with two sugar chains is independent of membrane cholesterol while those without sugars are cholesterol-dependent. The number of side chains influences both hemolytic activity and membrane permeability (Gögelein \& Hüby, 1984; Apers et al., 2001). It was also proved that saponins possessing two side chains induce less activity than those with only one sugar side chain. Taking all information into consideration, the specific effects of saponins may be due to the combination of target membrane composition, the type of the saponin side chain(s) and the nature of the aglycone (Bachran et al., 2006). However, permeabilizing effect is characteristic of saponins administered in high concentrations (above $100 \mu \mathrm{M}$ ). Apart from membrane permeabilization, saponins may affect intracellular signaling pathways involved in crucial physiological processes. This type of activity is characteristic of the compounds administered at relative- 
ly low concentrations (below $10 \mu \mathrm{M}$ ) and may be crucial for their chemopreventive effects and further applications in treatment.

To date, the first report on antitumor activity of saponins has been published in 1976 (Ebbesen et al., 1976), whereas the growing interest in this class of compounds as potential antitumor agents could be clearly seen since the 1990s. One of the first studies on the impact of triterpenoid saponins on tumor cells was performed on mouse models in vivo. It showed that saponin isolated from Bolbostemma paniculatum (tubeimoside) inhibits the growth of melanoma in mouse (Yu et al., 1992). Concomitantly, it has been shown that saikosaponin-a inhibits proliferation of ovarian cancer cells in vitro while saikosaponin-c and ginsenosides were not active (Okita et al., 1993). Perhaps it has been the first attempt to predict the biological activity of saponosides from a Structure-Activity Relationship (SAR). Basically, this approach tries to elucidate the relationships between the chemical structure of individual parts of saponosides (glycon and aglycone) and the activity of the whole compound. However, due to enormous structural diversity of triterpenoid saponins, formulation of SARs that would holistically address the molecular mechanisms of their action is a real challenge to be faced in future. Since then, the number of reports on this topic has been growing exponentially and the in vitro data on the activity of saponins are recently more frequently complemented by in vivo analyses. They helped to identify 3 basic categories of saponoside effects on tumor cells. These include: (1) cytostatic (2) pro-apoptotic and (3) anti-metastatic effects. Saponins also sensitize cancer cells to the cytostatic, pro-apoptotic and anti-metastatic effects of other chemotherapeutic drugs (Fig. 1).

\section{Cytostatic activity of saponins}

The ability to uncontrolled proliferation is one of the basic characteristics of tumor cells. Therefore, chemotherapeutic agents with cytostatic properties that lead to inhibition of cell division are commonly used in cancer treatment. A major breakthrough in understanding the behavior of tumor cells and their response to medication was the elucidation of cell cycle checkpoint alterations in tumor cells. Compounds with cytostatic activity may activate cell cycle arrest through the damage to mitotic spindle or via a direct effect on signaling pathways that regulate cell proliferation. Several triterpene saponins have well documented antiproliferative activity, and mechanism of action of these compounds varies depending on the type of saponin and on the cell type (Masullo et al., 2014). Effect of triterpenoid saponins on the proliferation of various cancer cells is often discussed in the literature but the authors do not always address mechanisms of their action (Balsevich et al., 2012). Only in a few cases was the cell cycle-related effects of saponins considered in terms of their chemical structure and cell type. An illustrative example of such studies is provided by the analyses of the saponin isolated from Pulsatilla chinensis (Pulsatilla a), which was shown to inhibit hepatocellular carcinoma SMCC-7721 cells in G2/M phase. Pulsatilla $\mathrm{d}$ which is isolated from the same plant but has different chemical structure inhibits the proliferation of colon cancer cells by modulating AKT/mTOR signaling pathway (Son et al., 2013; Liu et al., 2014). Transition from G1 to $S$ phase depends on cyclin (D1 and E)/ CDK2 and CDK4 (cyclin-dependent kinase) complexes. It has been shown that the ginsenoside rich fraction, isolated from Sun Ginseng (KG-135) inhibit expression of CDK2 and CDK4 in human prostate cancer cells (DU145 and PC-3), thereby preventing the transition cells into the S phase (Yoo et al., 2010). Crude saponin fraction isolated from Camelia oleifera also induces changes in the cell cycle by increasing the expression of the p21 protein that is a major inhibitor of cell cycle and by reducing the expression of cyclin $\mathrm{D}$ in human breast cancer cells (MCF-7). It results in the arrest of cells in G1 phase (Chen et al., 2013). Interestingly, the same saponin can inhibit cells in the G1 and/or G2 phase in a dosedependent manner. Such an effect has been demonstrated for tubeimoside, which inhibits the cells in G2/M in small doses, whereas G1 block is observed together with its increased doses or prolong incubation time in human liver cancer cells (Hep-G2) (Yin et al., 2011). Saponin isolated from Astralagus membranaceus inhibit BGC-823 gastric cancer cells in the G0 phase of the cycle while incubation of HT-29 human colon cancer cells in the presence of extract induce accumulation in $\mathrm{S}$ phase and G2/M arrest (Tin et al., 2007; Wang et al., 2013).

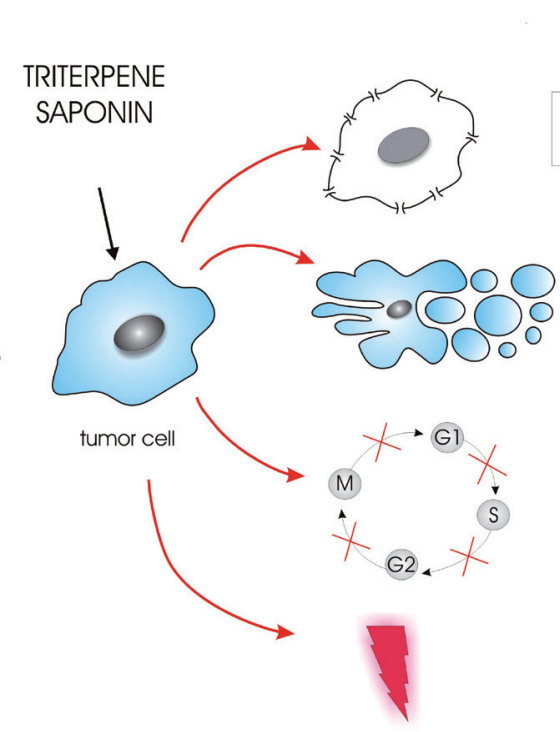

\section{Interaction The results of interaction}

\section{cell membrane} permabilization

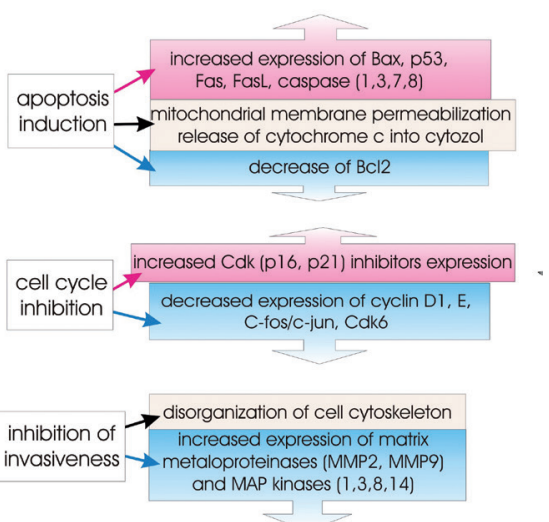


Saponins may also affect cancer cell proliferation through the impact on signaling pathways involved in the regulation of this process, for instance PI KK/Akt-dependent pathway. PI3K/Akt protein complexes lead to phosphorylation of numerous proteins, which are responsible for the stimulation of $\mathrm{G} 1 / \mathrm{S}$ transition and cell division. It has been shown that the triterpene saponins decrease Akt expression in human hepatoma cells (Hep-G2), which consequently leads to the inhibition of PI3K/Akt (Qin et al., 2014). Saponins also affect the expression of $\mathrm{NF} \varkappa \mathrm{B}$ and JNK (C-Jun N-terminal kinases), which are activated by $\mathrm{TNF}-\alpha$ (tumor necrosis factor type $\alpha$ ). NF $\varkappa$ B and JNK affects c-Jun which is involved in cellular exit from the G1 phase. Tubeimoside 1 (from Bolbostemma paniculatum) inhibits the expression of TNF- $\alpha$ and $\mathrm{NF} x \mathrm{~B}$ and activates JNK expression in human hepatoma cells (Hep G2) (Yin et al., 2011).

Noteworthy, saponins regulate cell proliferation through a direct effect on the cytoskeleton involved in the formation of mitotic spindle and the phenomena associated with the movement and responsible for keeping cell shape. Microtubules are highly dynamic structures (they depend on the equilibrium between the tubulin polimerization and depolymerization), and any disturbance of these processes leads to permanent perturbations of cell division. Interestingly, platycodin isolated from Platycodon grandiflorum, has been demonstrated to decrease the expression of the tubulin in leukemia cells (THP-1, U397, K562). Platycodin D has also the ability to interact with the microtubule cytoskeleton, leading to its destruction in a time and concentration-dependent manner, thus inhibiting cell divisions (Kim et al., 2008). Similarly, saponins isolated from Ardisia crenata (ardisciarispin A, B) could disassemble microtubule bundles in human hepatoma Bel-7402 cells which is responsible for the inhibition of their proliferation (Li et al., 2008).

\section{Pro-apoptotic activity of saponins}

Apoptosis, also known as programmed cell death, is a phenomenon that plays an important role in many physiological processes occurring in human body. Apoptosis helps to maintain the homeostasis of many tissues by regulating the equilibrium between cell proliferation and tissue hyperplasia (Bailon-Moscoso et al., 2014). Its biological significance relies on the elimination of "nonfunctional or redundant" cells without inducing extensive inflammatory responses and can be triggered by intrinsic mechanisms and extrinsic stimuli. The inner path of apoptosis may be activated in all cells of the body by genetic abnormalities and other damages, evoked by stress stimuli: hypoxia, free radicals, lack of adhesion (anoikis) (Fulda, 2015). For instance, extensive DNA damage in cells lead to the up-regulation of p53 that inhibits cell proliferation (partly in a p21/p27-dependent manner) and can induce pro-apoptotic program, through Bcl-2(B cell lymphoma-2), Bax- (BCL2-associated X protein) and Bid-dependent signaling (Sinha et al., 2013). They further cause cytochrome c/AIF release from mitochondrial membranes, which combines with APAF (Apoptosis Protease Activating Factor) to form apoptosome. Concomitantly the external cell death pathway may be activated through the interactions of "cell death" receptors (TNFR, FasL) with their ligands (TNF). The signal is then transduced by adapter proteins, such as FADD (Fas-associated Dead Domain). Intrinsic (apoptosomedependent) and extrinsic (FADD-dependent) pathways often converge at caspase 9, which is activated thanks to the presence of the C-terminal domain (DD - Death Domain) that is connected to the DD domain of receptor. Terminal domain of FADD - DED (Dead Effector Domain in turn activates caspase 3 and 7 (Green et al., 2014, Hassan et al., 2014). Caspase-dependent path-

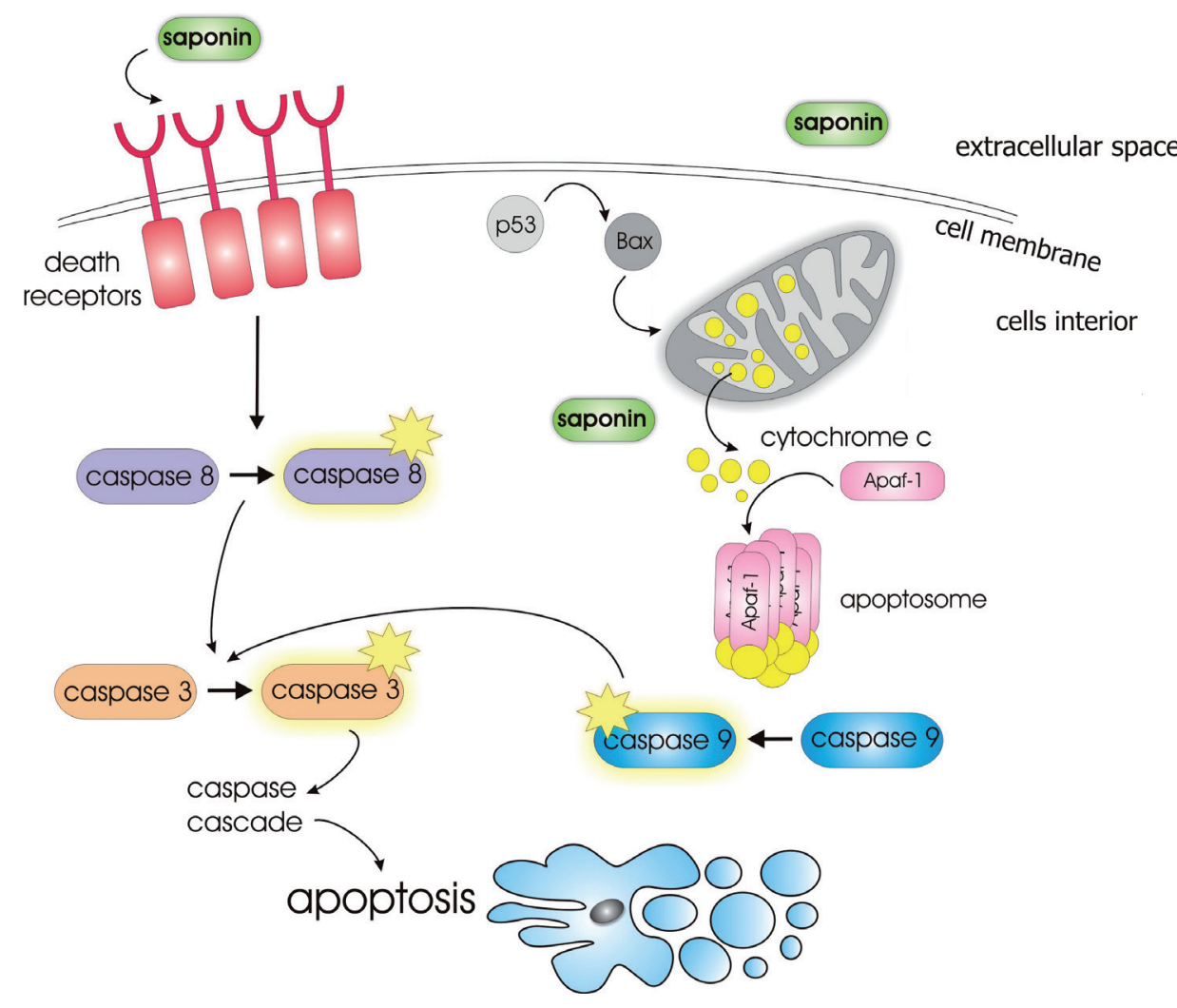

Figure 2. Mechanisms of pro-apoptotic effects of saponins. 
way is the most common mechanism of apoptosis, however its caspase-independent version has also been described (Kim et al., 2005). Cancer cells are more resistant to pro-apoptotic signals than their normal counterparts, therefore strategies based on substances that would increase their susceptibility to these signals is a promising anti-cancer strategy (Fulda, 2012). Importantly, apart from cytostatic activity, pro-apoptotic activity of triterpene saponins has been described.

Collective data show that saponins activate both caspase-dependent and caspase-independent pro-apoptotic pathways. Triterpene saponin ginsenoside Rh2 causes a decrease in mitochondrial membrane potential and release cytochrome $c$ from mitochondrial compartment, leading to the activation of caspase 3 and 9 in human leukemia Reh cells (Xia et al., 2014a). Saponins isolated from Platycodon grandiflorum (SPB) induced the apoptosis in primary prostate tumor cells RC-58T/hTER via increasing the expression of caspase 3, 9 and 8. Noteworthy, the translocation of AIF factor from mitochondria to cytosolic fraction, characteristic for the induction of caspase-independent pathway was alongside observed (Lee et al., 2013). Accordingly, ginsenoside Rk1 exerted the effect on human skin cancer cells (SK-MEL-2) through increasing the expression of protein Fas and FasL ligand. Simultaneously reduction in the expression of $\mathrm{Bcl} 2$ and increased expression of Bax was seen. A concomitant decrease of pro-caspase 8 and 3 may be indicative of the external/caspase-independent pathway induction (Kim et al., 2005). Saponin isolated from Anemone raddeana (raddenin A) induced the apoptosis in gastric cancer cells via the up-regulation of caspase 3 and 9, whereas it reduced Bax and Bcl-2 and Survivin expression levels (Xue et al., 2013). A similar activation was observed in the presence of saponins from Zizyphus jujuba seeds. These compounds induce apoptosis in HCT 116 cell lines of colorectal cancer by activation of caspase- 3 and PARP-1 and activation of caspase- 8 and FasL (Xu et al., 2014a). Thus, saponins can multidirectionaly induce apoptosis in cancer cells and normal cells. Protopanaxadiol (PPD) an aglycone typical of ginseng saponins was evaluated. Subsequently, authors characterized the downstream genes targeted by PPD in HCT-116 cancer cells. Data suggested that by regulating the interactions between p53 and DR4/DR5, the tumor necrosis factor-related apoptosis-inducing ligand (TRAIL) pathway played a key role in the action of PPD (Zhang et al., 2015). Saponins isolated from Giantleaf Ardisia rhizome (Rhiroma Ardisiae

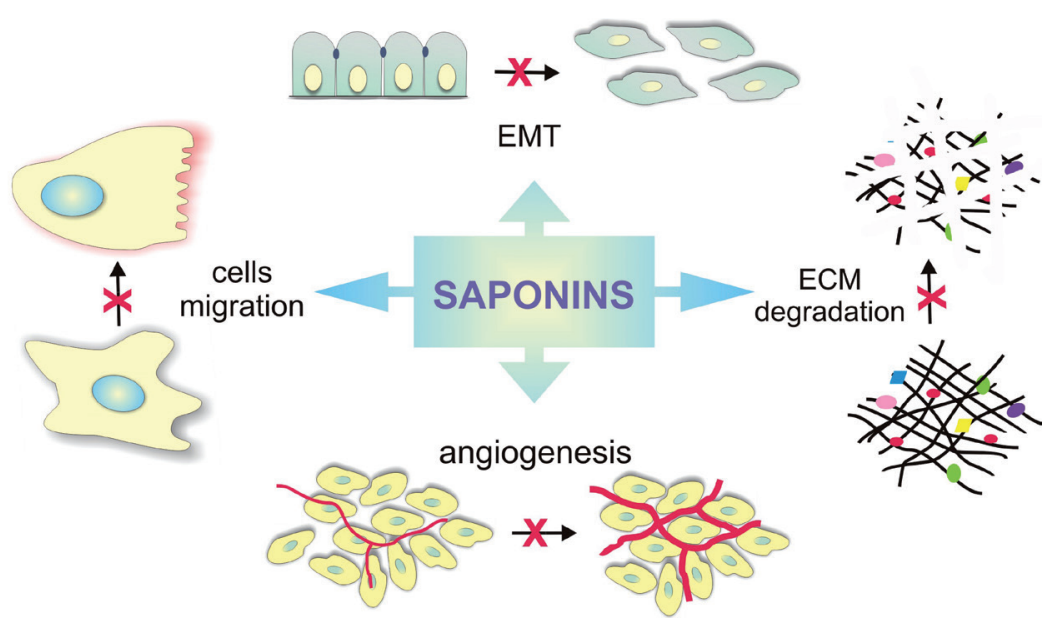

Figure 3. Possible mechanisms of anti-metastatic activity of saponins. gigantifoliae) - AG4 are also evaluated as pro-apoptotic agents. Release of caspase-3, caspase-8, and caspase- 9 was stimulated by AG4 in CNE (human nasopharyngeal carcinoma cells), and the decreased proliferation induced by AG4 was blocked by the inhibitor of pan caspase (ZVAD-FMK). In addition, both the FasL inhibitor (AF016) and the Bcl-2 family inhibitor (GX15-070) could prevent the cell apoptosis induced by AG4. These findings suggested that AG4-induced apoptosis in CNE cells involved both a death receptor pathway and a Bcl-2 family-mediated mitochondrial signaling pathway (Dong et al., 2015). Their effects are relatively universal and exerted at low (physiologically relevant) concentrations in a tumor cell- and saponin-specific manner (see Fig. 2).

\section{Effect of triterpenoid saponins on the invasive potential of cancer cells}

The history of oncology shows that cells which are characterized by a high metastatic potential also display relatively high resistance to anticancer agents. In most cases, the lethality of cancer results from the formation of secondary tumors. They are formed in progressing tumors in effect of the metastatic cascade which is a complex, multistage process triggered by the microevolution of invasive cell sub-populations (Friedl \& Alexander, 2011). During this process, the cells acquire the predilection to out-migrate from the primary tumor, actively infiltrate surrounding tissues in response to chemotactic stimuli (local invasion), enter the blood and lymph vessels, and subsequently colonize distant tissues and organs. Cellular properties that determine the ability of cancer cells to invade the tissue, include active cell migration, nanomechanical elasticity, regulation of cell adhesion and cytoskeleton dynamics but also production of metalloproteinases (MMPs), which allows them to penetrate tissue barriers (Xia et al., 2014a) (Fig. 3). Impaired cell-cell adhesion at the primary site is required for cancer cells to metastasize. Reduced E-cadherin is the indicator of loss of cell-cell adhesion. Rho GTPases, including Rac1, Cdc42 are important in the establishment of mature epithelial cell-cell junction. Rac1 and Cdc42 are key regulators of the actin cytoskeleton which coordinate cell migration and cell-cell adhesion. They are required for cadherin mediated cell-cell adhesion. Cdc42 and Rac1 directly regulate E-cadherin activity. Rac 1 activity increased in whole cell populations at different times after initiation of cell-cell contact, and was subsequently maintained at high level upon E-cadherin adhesion (Vega \& Ridley, 2008). Degradation of extracellular matrix (ECM) by proteolytic enzymes such as MMP-9 and MMP-2 is an essential step of cancer invasion. The expression of MMP-9 and MMP-2 is regulated by various factor, like $\mathrm{NF}-x \mathrm{~B}$, mitogen activated protein kinases (MAPK), extracellular signal-regulated kinases (ERK), c-Jun N- terminal kinase (JNK, p38 protein as well as phosphatidylinositol-3-kinase (PI3K/Akt) (Bauvois, 2012).

Numerous literature data suggest that the triterpene saponins affect the signaling pathways associated with the migration and invasion of tumor cells. Saponins lead to the inhibition of cell mi- 
gration as well as invasion in different ways, depending on their structure and type of targeted cells.

Saponins have been shown to prevent the invasion and migration of cancer cells by downregulating the expression of MMP-1, MMP-2, MMP-9 and MMP7 , by blocking the phosphorylation of ERK and p38 MAP kinase and by inhibiting the activation of AP-1, they can also inhibited the TNF- $\alpha$-induced activation of $\mathrm{NF}-x \mathrm{~B}$ and reduced the expression of MMP-9, thereby suppressing the invasion and migration of cancer cells. Moreover saponins can also change the expression of RhoGTPases (Rac 1, Cdc42). Furthermore, saponins regulate the expression of E-cadherin which is involved in cell-cell adhesion.

In numerous in vitro studies, saponosides, especially ginsenosides, were found to be effective in preventing invasion and metastasis of several types of cancer cells of human origin (Shibata et al., 2001; Nag et al., 2012; Choi et al., 2014). The saponins isolated from other plants are also examined in the context of anti-invasive effects but very often authors investigate the anti migratory properties using in vitro model including Transwell chamber, wound healing assay or scratch assay without detailed analyses of molecular mechanism of these action. An example of such a publication is investigation of anti migratory effects of total saponins isolated from Actinidia valvata on human hepatocellular cancer cells (Zheng et al., 2012) or evaluation of anti-migratory activity saponins isolated from Baccopa monnieri on human breast cancer tumor cell line (MDA-MB-231) (Peng et al., 2010). Only one report correlates anti-invasive effect of saponin isolated from Lysimachia ciliata (CIL 1) on human prostate cancer cell line (DU145) with changes in nanomechanical properties of the cancer cells (Koczurkiewicz et al., 2013A). Quite a few scientific papers describes the exact mechanism of action of triterpene saponins with particular focus on signaling pathways involved in tumor invasion process (Kim et al., 2014). A direct effect of saponins on cancer cell motility was demonstrated in a number of studies. For instance, numerous reports indicate that cancer cell invasiveness is regulated by small $G$ proteins of Rho family, which regulate cell migration via the effects on the dynamics of the cytoskeleton (Vega \& Ridley, 2008) and are targeted by saponins (Jiang \& Liu, 2011). Among them, Rho is involved in the formation of focal contacts and stress fibers, whereas Rac1 is responsible for the formation of lamellipodia and determination of rear-front polarity. In contrast, $\mathrm{Cdc} 42$ determines the formation of filopodia by the cell (Vega \& Ridley, 2008). Overexpression of Cdc 42 protein in tumor cells leads to inhibition of their movement. Additionally, this protein activates Rac 1, which also hampers processes of cell migration (Welchman et al., 2007).

Noteworthy, the saponins fraction (SSA) isolated from Asparagus officinalis activates $\operatorname{Rac} 1$ and Cdc 42 and decreases the expression of Rho in human breast, colon and pancreatic cancer cells, resulting in the disorganization of their cytoskeleton and the inhibition of their invasiveness (Wang et al., 2013b). Similarly, $\beta$-escin which is used in the treatment of chronic venous insufficiency, reduces the RhoA and Rock (Rho-associated protein kinase) protein levels in the cells isolated from metastatic lung cancer in a mouse model, thus reducing their metastatic potential (Patlolla et al., 2013). In addition, ginsenoside $\mathrm{Rd}$ inhibited the invasion and migration of HepG2 cells by inhibiting the phosphorylation of ERK1/2, p38 MAPK and by inducing focal adhesion formation (Yoon et al., 2012). Yet another triterpene saponins ardipusilloside I isolated from Ardisia pusilla inhibit invasive po- tential of human hepatocellular carcinoma cells (HepG2, SMMC-7721). Ardipusilloside I treated cells enhance Rac 1 , not Cdc 42 activity. Activation of Rac 1 protein leads to the upregulation of E-cadherin which subsequently increased cell to cell and cell to ECM adhesion and in consequence leads to significantly less metastasis in cancer cells (Lou et al., 2012). It has also been demonstrated that the inhibition of human hepatoma Hep G2 cell migration and invasion by ginsenoside $\mathrm{Rd}$ is accompanied by attenuated expression levels of E-cadherin and vinculin, and an increased expression of $\mathrm{N}$-cadherin. These data suggest that saponins can interfere with epithelial- mesenchymal transition (EMT), a process that primarily accounts for cancer cell invasiveness (da Silva et al., 2014). In addition, it was shown that ginsenoside 20(R)-Rg3 suppressed A549 lung cancer cell migration, invasion, and anoikis resistance by inhibiting the TGF- $\beta_{1}$-induced EMT (Kim et al., 2014). All of the mechanisms of action of saponins do not cover the possibilities of inhibition cancer cell invasion. The authors draw attention to the impact of saponins on MDM 2 protein. Expression of MDM 2 protein promotes cell motility and invasiveness, while overexpression of MDM 2 often correlate with late stage metastatic breast cancer. MDM 2 inhibition reduces the expression of EMT markers and decreases migration of cancer cells. Natural product of ginsenoside 25-OCH3-PPD suppressed cancer cell metastasis and altered the expression of EMT-related proteins, thus inhibiting cancer cells motility through decreased MDM 2 expression (Wang et al., 2012).

In contrast, ginsenoside $\mathrm{Rg} 3$ (isolated from ginseng root) increased the activation of p38 MAPK which led to the inhibition of prostate tumor PC-3M cell migration (Pan et al., 2012). This effect was ascribed to the inhibition of the activity of aquaporins (in particular, aquaporin 1, AQP1) in these cells. The primary function of aquaporins is to carry water to and from the cell, however they were also implicated in the regulation of cell movement and invasion. Therefore, the interaction of these compounds with AQP1 protein shows another mechanism, by which the saponins may inhibit the process of metastasis.

Importantly, triterpene saponins have been shown to inhibit the expression of matrix metalloproteinases in a number of tumor cell types. For instance, Astragalus saponins (AST), isolated from Astralagus membranaceus were reported to inhibit the transmigration through the matrigel covered membrane of human adenocarcinoma cells, which correlated with a significant decrease in the expression of metalloproteinases 9 and 2 (Auyeung et al., 2012). Accordingly, ginsenoside Rh2 reduced the invasiveness of pancreatic cancer cells, diminished their ability to transmigrate and considerably attenuated the expression levels of MMP 9 and 2 (Tang et al., 2013). Furthermore, raddeanin $\mathrm{A}$ the triterpenoid saponin present in Anemone raddeana Regel., inhibits the invasion, migration and adhesion of human gastric cancer cell lines by down-regulation of MMP-2, MMP-9, and MMP-14 and up-regulation of RECK (reversion inducing cysteine rich protein with Kazal motifs) (Xue et al., 2013). Accordingly, ginsenoside $\mathrm{Rd}$ inhibited the invasion and migration of HepG2 cells by reducing the expression of MMP-1, MMP-2, MMP-7 (Yoon et al., 2012). Triterpene saponin kalopanaxasaponin $\mathrm{A}$, isolated from the plant, which was used traditionally for treatment rheumatoid arthritis (Kalopanax pictus), reduced MMP-9 expression in MCF-7 human cancer breast cell line, by blocking the activation of NF- $x \mathrm{~B}$ and AP-1 transcription factor via PI3K/Akt, 
PKC mediated extracellular signaling pathways (Park et al., 2009). Saponins derived from plant Platycodon grandiflorum (CKS) inhibit HT-180 cell invasion by reducing MMP-2 and MMP-9 activity but the mechanism of action used by saponins is different. CKS suppress the expression of MMP-9 protein, mRNA transcription activity levels through suppression of nuclear factor $\mathrm{NF}-x \mathrm{~B}$ activation without changing tissue inhibitor of metalloproteinases level (TIMP-1) (Lee et al., 2008). These studies correlated the impact of saponins on invasive potential of cancer cells with their proteolytic activity (Mason \& Joyce, 2011).

It can be seen that in recent years there has been tremendous progress in understanding how saponins influence the invasive potential of cancer cells. Saponins inhibit cancer cell invasion by acting on many signaling pathways related to the promotion and progression of cancer. Their effectiveness is very high, often they exhibit selectivity and inhibit migration of invasive cancer cells more than of their less malignant counterparts (Koczurkiewicz et al., 2013A). Studies of anti-invasive activity of triterpenoid saponins also include experiments using in vivo models. Much of this work however combines the study of anti-invasive activity of saponins to their effects on angiogenesis process. It has been proved that these compounds in addition to the effect of reducing the invasive activity also can inhibit the growth of new blood vessels within the tumor which is crucial from the point of view cancer growth (Xiao et al., 2014).

\section{VERSATILITY OF ANTI-CANCER SAPONIN EFFECTS - IMPLICATIONS FOR CANCER THERAPY}

\section{Cancer cell-selectivity of saponin activity}

The results reviewed above indicate that, in addition to a cytostatic and pro-apoptotic activity, some of the saponins can inhibit cell migration and cancer invasion. A number of saponins exerts impressive anti-cancer effects and may help to develop advantageous anti-cancer regimens. Dependent on the saponins tested and the target cells, they induce apoptosis and cell cycle arrest and attenuate cancer cell invasiveness. Whereas an increased interest in anti-cancer effects of triterpene saponins could be observed in recent years, only rarely were their effects on cancer cells compared with their interference with the function of normal cells (Gajdus et al., 2010; Li et al., 2014; Zhang et al., 2014). This problem also touches the selectivity of saponin effects on cancer cells, which is crucial for their systemic tolerability. In some cases, pro-apototic effects of saponins on cancer cells were accompanied by a lack of such effects on normal cells. For instance, saponin isolated from the plant Gypsobila oldbamiana induced apoptosis in the liver cancer cells while normal liver cells were insensitive (Zhang et al., 2013). Similar results were obtained for saponins isolated from Platycodon grandiflorum. High efficiency and specificity of saponin effects on cancer cells may suggest that they could exert their anti-cancer activity without considerable side-effect. Saponin isolated from tomato ( $\alpha$ tomatine) inhibited growth of human prostatic adenocarcinoma cells (PC-3), induced their apoptosis and suppressed NF$x \mathrm{~B}$ nuclear translocation which in turn resulted in strong inhibition of $\mathrm{NF}-x \mathrm{~B}$ activation. It was consistent with a decreased nuclear levels of NF- $x \mathrm{~B} / \mathrm{p} 65$ and $\mathrm{NF}-x \mathrm{~B} / \mathrm{p} 50$. The ability of $\alpha$ tomatine to inhibiting $\mathrm{NF}-x \mathrm{~B}$ activation by blocking nuclear translocation of $\mathrm{NF}-x \mathrm{~B} / \mathrm{p} 65$ and $\mathrm{NF}-x \mathrm{~B} / \mathrm{p} 50$ transcription factors suggests its promising role in prostate cancer prevention. What is more, $\alpha$ tomatine is less toxic to both normal human liver WRL68 and normal human prostate RWPE-1 cells (Lee et al., 2013).

On the other hand, not all saponins exhibit selectivity in their action. An example might be the saponins isolated from Bolbostemma paniculatum (TBMS I) which posses anti-cancer activity against several human cancer cells lines (human leukemia HL-60, nosopharyngeal carcinoma CNE-2Z, and HeLa cell lines). Pharmacokinetics study of TBMS I indicated that this saponin preferentially accumulates in the liver. This suggests that the liver may be primary a target of TBMS I toxicity. In vitro analyses (L-02 normal liver cells) showed that it can induce cytotoxic effects and apoptosis in normal cells. Therefore, its use in practice must be subjected to a more careful analysis (Wang et al., 2011). An interesting direction of investigation is the search for new activities of saponins, which have proven medicinal properties.

Specificity of the saponins effects may concern not only their impact on the tumor and normal cells but also their various effects on tumor cells of different origin. Saponin isolated from Aesculus hipocastanum (escin) possesses documented vasoprotective activity and excellent tolerability.

Cytotoxicity analyses show that escin reduces viability of human lung cancer (A-549), human pancreatic cancer (PANC-1) as well as human acute leukemia Jurkat cells while human ovarian carcinoma SK-OV3 cells remain insensitive on the effect of escin (Zhang et al., 2011). Accordingly, twenty saponins isolated from Ardisia japonica were evaluated for their anti-proliferative activity on human liver cancer cells and normal liver cells. Eight saponins selectively inhibited the growth of liver cancer cells Bel-7402 and HepG2 without affecting the survival of the normal cells HL-7702. What is worth noting, selectivity of these saponins depend on the presence of a 133,28-epoxy bridge in aglycone ( $\mathrm{Li}$ et al., 2012). Saponins isolated from Lysimachia ciliata, which have the same epoxy bridge in their structure, exhibit selectivity for human prostate cancer and normal cells. Both analyzed compounds (CIL 1 and CIL 2) inhibited invasion and induced apoptosis in prostate cancer cells while normal cells were insensitive to their action. Moreover, CIL 1 exerted a stronger effect on invasive human prostate cancer cells than on their less invasive counterparts (Koczurkiewicz et al., 2013B).

\section{Versatility of saponins action on cancer cells}

Undoubtedly, the state of knowledge on the triterpenoid saponins and on the mechanisms of their action on cancer cells (in vitro and in vivo) has considerably expanded over last years, but this expansion hardly compensates the number of newly isolated compounds. Noteworthy, their apoptosis- and cell cycle-related effects on cancer cells and on their invasivenes are cell type-, and agent-specific. However, only relatively few reports describe the effect of saponins on the prostate cells. Concomitantly, these studies did not consider cytostatic and pro-apoptotic effects of saponins in terms of cancer cell invasiveness. In one of our studies was the versatility of their effects considered in terms of their possible application on tumors at different stages of development. Combined pro-apoptotic and anti-invasive effects of saponins add to this complexity, which is rarely addressed in the literature. An example of this complexity is provided by the compounds (triterpene saponins) isolated from Lysimachia ciliata. These saponins affect prostate cancer cells, by direct inhibition of cancer 
cells invasion, migratory potential as well as induction of apoptosis and inhibition of prostate cancer growth at a very low concentration $(4 \mu \mathrm{M})$. This report was also the first which drew attention to the impact of saponins on nanomechanical properties of cancer cells. Changes of the cell elasticity correlate often with their invasive potential (Cross et al., 2008). We have been the first who showed that saponins can affect the nanomechanical properties of cancer cells which may be important for understanding the mechanism of their anti-invasive activity. Data which we obtained strongly suggest that the specificity of action of triterpenoid saponins concerns not only the proapoptotic or cytostatic activity, but also unambiguously prove the effects of these compounds on the process of cell migration and diapedesis. Our results may be very important for understanding the mechanisms of their anti-invasive activity (Koczurkiewicz et al., 2013). Moreover, cytotoxic activity of saponin isolated from the root of Adenophora triphylla was investigated against human gastric cancer (AGS), human lung cancer (A-549) and human liver cancer cells (Hep G2). Authors decided to study the molecular mechanism of action of this compound only on human gastric cancer cells. This compound induced apoptosis and autophagy in cancer cells by the interference with Akt/NF- $x$ B and p38 pathways in AGS cells in concentration range $10-30 \mu \mathrm{M}$, but what is worth mentioning it did not inhibit cancer cell proliferation and did not induce changes in cell cycle distribution (Chun et al., 2014).

The previously described saponins isolated from Lysimachia sp. were completely new compounds, with unexplored anti-cancer activity. On the other hand in the literature we can find information about examining the activity of well known, previously described structures. An example of such research is the publication about the effect of saponins called platycodin D, isolated from Platycodinis radix. The anti-cancer effects of platycodin D are well described in literature (Kim et al., 2008; Wu et al., 2012) but most of the authors focus on their antiproliferative and proapoptotic effects on breast, prostate, leukemia or lung cancer cells. Platycodin D can also inhibit adhesion, migration and invasion in Hep G2 cells in concentration $10 \mu \mathrm{M}$ but authors failed to mention effects of these compound on human normal cells ( $\mathrm{Li}$ et al., 2014). On the whole it is difficult to conclude from the literature how platycodin D influences normal cells of the body. For obvious reasons, concentrations used in in vitro studies hardly correspond to the therapeutic doses. At the moment, there is no data about the concentrations of saponins that would be sufficient to achieve a therapeutic effect in humans.

\section{Effect of saponins on cancer cell sensitivity to chemotherapeutic drugs}

Safety and selectivity of anti-cancer drug are their extremely valuable attribute for application in chemotherapy. The search for new therapeutic strategies should not only focus on the extension of patients life but also on improving its living standard. Therefore, more and more side effects of chemotherapy are taken into account to mitigate their unpleasant effects for the patient. Compilations of several drugs, which activities complement each other, are frequently used in modern chemotherapeutic strategies. An interesting research field is the use of common chemotherapeutic agents together with plant compounds, including saponins (Fuchs et al., 2009). For instance, the beneficial effects of plant polyphenols present in green tea combined with cyklooxygenase inhibitor has been proved in human prostate tumor cells model in vivo and in vitro
(Adhami et al., 2007). Similarly, combination of resveratrol with vinorelbine inhibited the proliferation of DU145 cells (Scifo et al., 2006). Till now relatively little attention has been paid to the potential suitability of saponins for combined anti-cancer therapies. Only a few reports have been published that address synergistic effects of saponins that enhance their proapoptotic and cytotoxic activity (Eid et al., 2012; Li et al., 2012). Studies published so far showed that ginsenoside $\mathrm{Rg} 3$ significantly increased the bioavailability of paclitaxel in a mouse model of breast cancer. On the other hand cyclamine, isolated from Ardisia japonica enhances the effects of three chemotherapeutic drugs: 5-fluorouracil, cisplatin and epirubicin on the liver cancer Bel-7402 and Hep G2 cells. In contrast, these combinations remained non-toxic to normal liver cells HL-7702 (Li et al., 2014a). Panaxadiol isolated from Panax ginseng sensitized in cancer intestinal cells to caspase 3/9-dependent apoptosis induced by irinotecan (Du et al., 2012). Until today, it has not been established clearly what is the physiological mechanism responsible for the synergy of saponins with chemotherapeutic agents. Recent studies suggest that synergy can be modulated by various effects based on different mechanisms of action. It has been demonstrated that the synergy of saponins isolated from ginseng (PNS) with cisplatin depends on the functional status of gap junctions in tumor cells. When the inhibitor of gap junctional channels was used, the synergy of saponins with cisplatin was not observed, which suggests that gap junctions are directly involved in this reaction $(\mathrm{Yu}$ et al., 2012). These studies draw our attention to a very important problem in cancer biology, which is communication of cancer cells. Gap junctions are specialized cell-cell junction that directly link cytoplasmic compartments of neighboring cells. They play an important role in maintaining homeostasis, control the growth and differentiation of cells in the body. As it turns out, they may be directly involved in the cell response to the applied therapy (Czyż et al., 2012). Other results show that saikosaponis sensitize cancer cells to the effects of cisplatin by entering them toward apoptosis, and caspase inhibitor inhibits apoptotic pathway/revoke the apoptotic effect. In cells treated with cisplatin and saponins together, increased production of reactive oxygen species (ROS) was observed. An interesting result was obtained with the Siha cells (naturally resistant to cisplatin). When they were used together with the saponins they start to be very susceptible to chemotherapy (Wang et al., 2010). Cisplatin is not the only chemotherapeutic agent used in combination therapy with triterpene saponins. Another commonly used in cancer therapy drug is paclitaxel. Researchers proved that paclitaxel used in conjunction with saponins in subtoxic doses decreased the viability of prostate cancer cells (PC3), but the normal cells of the prostate (RWPE-1) remained insensitive to these compounds. Tumor cells reacted with increased expression of proapoptotic proteins (Bad) and decreased expression of anti-apoptotic proteins ( $\mathrm{Bcl}-2, \mathrm{Bcl}-\mathrm{x})$ (Lee et al., 2013b).

Saponins (ginsenoside Rg3) applied in combination with docetaxel inhibit the activation of $\mathrm{NF}-x \mathrm{~B}$, which is responsible for prostate tumor cell resistance to chemotherapy. None of the substances used alone does not have this effect. Studies in human prostate cancer cells (DU145, PC-3, LNCaP) show that expression of the enzyme caspase 3 and 9 is much stronger in the case of using saponin and docetaxel together, and expression of cell cycle regulatory proteins - cyclin B, D1 and E is inhibited (Kim et al., 2010). Little information is available about the effects of combined therapies on cancer invasion. Our study is one of the first reports on the impact 
of known cytostatic drug (mitoxantrone) combined with triterpene saponins (Lclet 4) isolated from Lysimachia clethroides on invasive activity of human prostate cancer cells (Koczurkiewicz et al., 2013B). The results show that the activity of Lclet 4/MTX was significantly higher than that of both substances used alone. In addition, it was highly selective because Lclet4/MTX treatment was toxic to cancer but not to normal cells. Co-administration of the compounds (Lclet 4 and MTX) significantly inhibits migration of prostate cancer cells DU-145 and causes changes in actin cytoskeletal organization and microtubules. Saponin administration (Lclet 4) with mitoxantrone also resulted in inhibition of tumor cell transmigration. It is worth noting that the saponin Lclet 4 used individually, even at higher concentrations did not result in inhibition of tumor cell transmigration (Koczurkiewicz et al., 2013B). These data show that the combination anticancer drugs with saponins is a promising strategy of cancer treatment.

\section{CONCLUSION}

Experiments which showed saponins activity in cellular models (in vitro) and with animals (in vivo) began in 90s of the last century. Since then, the number of newly isolated and described triterpene saponins has been increasing constantly and many previously unknown compounds have been identified due to improved purification and detection methods. Many of these compounds exert impressive anti-cancer effects and may help to develop novel anti-cancer regimens. However, the knowledge that has been brought by decades of extensive research on saponins is still not sufficient to fully describe the complexity of their action. Whereas biological properties of saponins are closely dependent on their chemical structure, there is still no reliable approach which would allow to predict the activity of a given compound in relation to its chemical structure. Things are not helped by the fact that the isolation of saponins from plant material is a difficult and time-consuming. Conceivable complexity of their synthesis on an industrial scale add to the limitations of their application in medicine. Finally, the quality and quantity of therapeutic effects of saponins depend on the cellular context, which is closely related to the momentary genomic and proteomic status of the cells. Therefore, only the projects that combine the research on the structure of saponins and their pharmacological and pharmacokinetic profile with the genomic and proteomic approaches focused on cellular specificity of saponin activities, may give the chance to implement these promising plant compounds into new anti-cancer regimens.

\section{Acknowledgements}

Conflict of interest: The authors declare no conflict of interests.

\section{REFERENCES}

Abbruscato P, Tosi S, Crispino L, Biazzi E, Menin B, Picco AM, Pecetti L, Avato P, Tava A (2014) Triterpenoid glycosides from medicago sativa as antifungal agents against Pyricularia oryzae. J Agric Food Chem 62:11030-11036 http://dx.doi.org/10.1021/jf5049063.

Adhami VM, Malik A, Zaman N, Sarfaraz S, Siddiqui IA, Syed DN, Afaq F, Pasha FS, Saleem M, Mukhtar H (2007) Combined inhibitory effects of green tea polyphenols and selective cyclooxygenase-2 inhibitors on the growth of human prostate cancer cells both in vitro and in vivo. Clin Cancer Res 13: 1611-1619.

Apers S, Baronikova S, Sindambiwe JB, Witvrouw M, De Clercq E, Vanden Berghe D, Van Marck E, Vlietinck A, Pieters L (2001) Antiviral, haemolytic and molluscicidal activities of triterpenoid sapo- nins from Maesa lanceolata: establishment of structure-activity relationships. Planta Med 67: 528-532.

Asha MK, Debraj D, Prashanth D, Edwin JR, Srikanth HS, Muruganantham N, Dethe SM, Anirban B, Jaya B, Deepak M, Agarwal A (2013) In vitro anti-Helicobacter pylori activity of a flavonoid rich extract of Glyyrrbiza glabra and its probable mechanisms of action. J Ethnopharmacol 145: 581-586. http://dx.doi.org/10.1016/j. jep.2012.11.033.

Auyeung KK, Woo PK, Law PC, Ko JK (2012) Astragalus saponins modulate cell invasiveness and angiogenesis in human gastric adenocarcinoma cells. J Ethnopharmacol 141: 635-641. http://dx.doi. org/10.1016/i.jep.2011.08.010.

Baade PD, Youlden DR, Krnjacki LJ (2009) International epidemiology of prostate cancer:geographical distribution and secular trends. Mol Nutr Food Res 53: 171-184. doi: 10.1002/mnfr.200700511.

Bachran C, Sutherland M, Heisler I, Hebestreit P, Melzig MF, Fuchs H (2006) The saponin-mediated enhanced uptake of targeted saporinbased drugs is strongly dependent on the saponin structure. Exp Biol Med (Maywood) 4: 412-420.

Bailón-Moscoso N, Romero-Benavides JC, Ostrosky-Wegman P (2014) Development of anticancer drugs based on the hallmarks of tumor cells. Tumour Biol 35: 3981-3995. doi: 10.1007/s13277-014-1649-y.

Balsevich JJ, Ramirez-Erosa I, Hickie RA, Dunlop DM, Bishop GG, Deibert LK (2012) Antiproliferative activity of Saponaria vaccaria constituents and related compounds. Fitoterapia 83: 170-181. http:// dx.doi.org/10.1016/j.fitote.2011.10.010.

Bauvois B (2012) New facets of matrix metalloproteinases MMP-2 and MMP-9 as cell surface transducers: Outside-in signaling and relationship to tumor progression. Biochim Biophys Acta 1825: 29-36. http://dx.doi.org/10.1016/j.bbcan.2011.10.001.

Bishayee A, Shamima A, Brankov N, Marjorie P (2011) Triterpenoids as potential agents for the chemoprevention and therapy of breast cancer. Front Biosci (Landmark ed) 16: 980-996.

Bommareddy A, Eggleston W, Prelewicz S, Antal A, Witczak Z, McCune DF, Vanwert AL (2013) Chemoprevention of prostate cancer by major dietary phytochemicals. Anticancer Res 33: 4163-4174.

Böttger S, Westhof E, Siems K, Melzig MF (2013) Structure-activity relationships of saponins enhancing the cytotoxicity of ribosome-inactivating proteins type I (RIP-I). Toxicon 73: 144-150. http://dx. doi.org/10.1016/j.toxicon.2013.07.011.

Cesarone MR, De Sanctis MT, Incandela L, Belcaro G, Griffin (2001) Microvascular changes in venous hypertension due to varicose veins after standardized application of Essaven gel-a placebo-controlled, randomized study. $M$ Angiology 52: 11-16.

Chen L, Chen J, Xu H (2013) Sasanquasaponin from Camellia oleifera Abel. induces cell cycle arrest and apoptosis in human breast cancer MCF-7 cells. Fitoterapia 84: 123-129. http://dx.doi.org/10.1016/j. fitote.2012.11.009.

Choi JH, Hwang YP, Kim HG, Khanal T, Do MT, Jin SW, Han HJ, Lee HS, Lee YC, Chung YC, Jeong TC, Jeong HG (2014) Saponins from the roots of Platycodon grandiflorum suppresses TGF $\beta 1$-induced epithelial-mesenchymal transition via repression of PI3K/Akt, ERK1/2 and Smad2/3 pathway in human lung carcinoma A549 cells. Nutr Cancer 66: 140-151. http://dx.doi.org/10.1080/0163558 1.2014.853087.

Chun J, Kang M, Kim YS (2014) A triterpenoid saponin from Adenophora triphylla var. japonica suppresses the growth of human gastric cancer cells via regulationof apoptosis and autophagy. Tumor Biol 35: 12021-12030. doi 10.1007/s13277-014-2501-0.

Cross SE, Jin YS, Tondre J, Wong R, Rao J, Gimzewski JK (2008) AFM-based analysis of human metastatic cancer cells. Nanotechnology 19: 38-47. http://dx.doi.org/10.1088/0957-4484/19/38/384003.

Czyż J, Szpak K, Madeja Z (2012) The role of connexins in prostate cancer promotion and progression. Nat Rev Urol 9: 274-282. doi:10.1038/nrurol.2012.14.

Dong XZ, Xie TT, Zhou XJ, Mu LH, Zheng XL, Guo DH, Liu P, Ge XY(2015) AG4, a compound isolated from Radix Ardisiae Gigantifoliae, induces apoptosis in human nasopharyngeal cancer $\mathrm{CNE}$ cells through intrinsic and extrinsic apoptosis pathways. Anticancer Drugs. 26: 331-342. http://dx.doi.org/10.1097/cad.0000000000000193.

Du GJ, Wang CZ, Zhang ZY, Wen XD, Somogyi J, Calway T, He TC, Du W, Yuan CS (2012) Caspase-mediated pro-apoptotic interaction of panaxadiol and irinotecan in human colorectal cancer cells. J Pharm Pharmacol 64: 727-734. http://dx.doi.org/10.1111\%2Fj.20427158.2012.01463.x.

Ebbesen P, Dalsgaard K, Madsen M (1976) Prolonged survival of AKR mice treated with the saponin adjuvant Quil A. Acta Patbol Microbiol Scand A. 84: 358-360.

Eid SY, El-Readi MZ, Wink M (2012) Synergism of three-drug combinations of sanguinarine and other plant secondary metabolites with digitonin and doxorubicin in multi-drug resistant cancer cells. Phytomedicine 19: 1288-1297. http://dx.doi.org/10.1016/j. phymed.2012.08.010

Francis G, Kerem Z, Makkar HP, Becker K (2002) The biological action of saponins in animal systems: a review. Br J Nutr 88: 587-605. 
Friedl P, Alexander S (2011) Cancer Invasion and the Microenvironment: Plasticity and Reciprocity. Cell 147: 992-1009. http://dx.doi. org/10.1016/j.cell.2011.11.016.

Fuchs H, Bachran D, Panjideh H, Schellmann N, Weng A, Melzig MF, Sutherland M, Bachran C (2009) Saponins as tool for improved targeted tumor therapies. Curr Drug Targets 10: 140-151. http://dx.doi. org/10.2174/138945009787354584.

Fulda S (2012) Shifting the balance of mitochondrial apoptosis: therapeutic perspectives. Front Oncol 8: 121-128. http://dx.doi. org/10.3389/fonc.2012.00121.

Fulda S (2015) Targeting extrinsic apoptosis in cancer: Challenges and opportunities. Semin Cell Dev Biol 39: 20-25. http://dx.doi. org/10.1016/j.semcdb.2015.01.006.

Gajdus J, Kaczyński Z, Kawiak A, Lojkowska E, Stefanowicz-Hajduk J, Ochocka JR, Stepnowski P (2010) Isolation and identification of cytotoxic compounds from the rhizomes of Paris quadrifolia L. Pharmacogn Mag 4: 324-333. http://dx.doi. org/10.4103\%2F0973-1296.133289.

Gögelein H, Hüby A (1984) Interaction of saponin and digitonin with black lipid membranes and lipid monolayers. Biochim Biophys Acta 773: 32-38.

Green DR, Galluzzi L, Kroemer G (2014) Cell biology. Metabolic control of cell death. Science 19: 345-361. http://dx.doi. org $/ 10.1126 \% 2$ Fscience. 1250256.

Hanahan D, Weinberg RA (2000) The hallmarks of cancer. Cell 100: $57-70$.

Hanahan D, Weinberg RA (2011) Hallmarks of cancer: the next generation. Cell 144: 646-674. http://dx.doi. org $/ 10.1155 \% 2 \mathrm{~F} 2014 \% 2 \mathrm{~F} 150845$.

Hassan M, Watari H, Almaaty AA, Ohba Y, Sakuragi N (2014) Apoptosis and molecular targeting therapy in cancer. BioMed Research International 2014: 150845 doi: 10.1155/2014/150845. http://dx.doi. org/10.1155/2014/150845.

Holzinger F, Chenot JF (2011) Systematic review of clinical trials assessing the effectiveness of ivy leaf (Hedera helix) for acute upper respiratory tract infections. Evid Based Complement Alternat Med doi: 10.1155/2011/382789. http://dx.doi. org/10.1155\%2F 2011\%2F382789.

Jiang YL, Liu ZP (2011) Natural products as anti-invasive and anti-metastatic agents. Curr Med Chem 6: 808-829.

Kim R, Emi M, Tanabe K. (2005) Caspase-dependent and -independent cell death pathways after DNA damage (Review). Oncol Rep 14: 595-599.

Kim MO, Moon DO, Choi YH, Lee JD, Kim ND, Kim GY (2008) Platycodin D induces mitotic arrest in vitro, leading to endoreduplication, inhibition of proliferation and apoptosis in leukemia cells. Int J Cancer 122: 2674-2681. DOI: 10.1002/ijc.23442.

Kim SM, Lee SY, Cho JS, Son SM, Choi SS, Yun YP, Yoo HS, Yoon do Y, Oh KW, Han SB, Hong JT (2010) Combination of ginsenoside $\mathrm{Rg} 3$ with docetaxel enhances the susceptibility of prostate cancer cells via inhibition of NF-kappaB. Eur J Pharmacol 631: 1-9. http://dx.doi.org/10.1016/j.ejphar.2009.12.018.

Kim YJ, Choib W-I, Jeon B-N, Choi K-C, Kim K, Kimf T-J, Hama J, Jangi HJ, Kang KS, Koh K (2014) Stereospecific effects of ginsenoside 20-Rg3 inhibits TGF- $\beta 1$-induced epithelial-mesenchymal transition and suppresses lung cancer migration, invasion and anoikis resistance. Toxicology 322: 23-33. http://dx.doi.org/10.1016/j. tox.2014.04.002.

Koczurkiewicz P, Podolak I, Skrzeczyńska-Moncznik J, Sarna M, Wójcik KA, Ryszawy D, Galanty A, Lasota S, Madeja Z, Czyż J, Michalik M (2013a) Triterpene saponosides from Lysimachia ciliata differentially attenuate invasive potential of prostate cancer cells. Chem Biol Interact 206: 6-17. http://dx.doi.org/10.1016/j.cbi.2013.08.003.

Koczurkiewicz P, Podolak I, Wójcik KA, Galanty A, Madeja Z, Michalik M, Czyż J (2013b) Lclet 4 enhances pro-apoptotic and anti-invasive effects of mitoxantrone on human prostate cancer cells - in vitro study. Acta Biochim Pol 60: 331-338.

Lee KJ Hwang SJ, Choi JH, Jeong HG (2008) Saponins derived from the roots of Platycodon grandiflorum inhibit HT-1080 cell invasion and MMPs activities: Regulation of $\mathrm{NF}-x \mathrm{~B}$ activation via ROS signal pathway. Cancer Lett 268: 233-243. http://dx.doi.org/10.1016/j.canlet.2008.03.058.

Lee JH, Oh E-K, Cho H-C, Kim J-K, Lee M-K, Seo K-I (2013a) Crude saponins from Platycodon grandiflorum induce apoptotic cell death in RC-58T/h/SA\#4 prostate cancer cells through the activation of caspase cascades and apoptosis-inducing factor. Oncology Reports 29: 1421-1428. doi: 10.3892/or.2013.2256.

Lee ST, Wong PF, Hooper JD, Mustafa MR (2013b) Alpha-tomatine synergises with paclitaxel to enhance apoptosis of androgen-independent human prostate cancer PC-3 cells in vitro and in vivo. Phytomedicine. 20: 1297-1305. http://dx.doi.org/10.1016/j. phymed.2013.07.002.

Li M, Wei SY, Xu B, Guo W, Liu DL, Cui JR, Yao XS (2008) Pro-apoptotic and microtubule-disassembly effects of ardisiacrispin $(\mathrm{A}+\mathrm{B})$, triterpenoid saponins from Ardisia crenata on human hepatoma Bel-7402 cells. I Asian Nat Prod Res 10: 739-446. doi: 10.1080/10286020802016198.

Li Q, Li W, Hui LP, Zhao CY, He L, Koike K (2012) 13,28-Epoxy triterpenoid saponins from Ardisia japonica selectively inhibit proliferation of liver cancer cells without affecting normal liver cells. Bioorg Med Chem Lett 22: 6120-6125. http://dx.doi.org/10.1016/j. bmcl.2012.08.027.

Li Q, Deng L, Li W, Koike K (2014a) Cyclamin, a natural 13,28-epoxy triterpenoid saponin, synergistically enhances the cytotoxicity of chemotherapeutic drugs in human liver cancer cells but not non-neoplastic liver cells. Planta Med 80: 409-414. http://dx.doi. org/10.1055/s-0034-1368198.

Li T, Xu WS, Wu GS, Chen XP, Wang YT, Lu JJ (2014b) Platycodin $\mathrm{D}$ induces apoptosis, and inhibits adhesion, migration and invasion in HepG2 hepatocellular carcinoma cells. Asian Pac J Cancer Prev 15: 1745-1749.

Liu WK, Xu SX, Che CT (2000) Anti-proliferative effect of ginseng saponins on human prostate cancer cell line. Life Sci 67: 1297-1306.

Liu Q, Chen W, Jiao Y, Hou J, Wu Q, Liu Y, Qi X (2014) Pulsatilla saponin A, an active molecule from Pulsatilla chinensis, induces cancer cell death and inhibits tumor growth in mouse xenograft models. J Surg Res 188: 387-395. http://dx.doi.org/10.1016/j. jss.2014.01.026.

Lorent JH, Quetin-Leclercq J, Mingeot-Leclercq MP (2014) The amphiphilic nature of saponins and their effects on artificial and biological membranes and potential consequences for red blood and cancer cells. Org Biomol Chem 12: 8803-8822. http://dx.doi.org/10.1039/ C4OB01652A.

Lou L, Ye W, Chen Y, Wu S, Jin L, He J, Tao X, Zhu J, Chen X, Deng A, Wang J (2012) Ardipusilloside inhibits survival, invasion and metastasis of human hepatocellular carcinoma cells. Phytomedicine 19: 603-608. http://dx.doi.org/10.1016/j.phymed.2012.01.003.

Man S, Gao W, Zhang Y, Huang L, Liu C (2010) Chemical study and medical application of saponins as anti-cancer agents. Fitoterapia 7 : 703-714. http://dx.doi.org/10.1016/j.fitote.2010.06.004.

Mason SD, Joyce JA (2011) Proteolytic networks in cancer. Trends Cell Biol 21: doi:10.1016/j.tcb.2010.12.002.

Masullo M, Calabria L, Gallotta D, Pizza C, Piacente S (2014) Saponins with highly hydroxylated oleanane-type aglycones from Silphium asteriscus L. Phytochemistry. 97: 70-80. http://dx.doi.org/10.1016/j. phytochem.2013.10.013.

Mu LH, Huang XW, Guo DH, Dong XZ, Liu P (2013) A new triterpenoid saponin from Ardisia gigantifolia. I Asian Nat Prod Res 15: 1123-1129. DOI: 10.1080/10286020.2014.958997.

Musende AG, Eberding A, Wood C, Adomat H, Fazli L, Hurtado-Coll A, Jia W, Bally MB, Guns ET (2009) Pre-clinical evaluation of Rh2 in PC-3 human xenograft model for prostate cancer in vivo: formulation, pharmacokinetics, biodistribution and efficacy. Cancer Chemother Pharmacol 64: 1085-1095. http://dx.doi.org/10.1007/s00280-0090965-1.

Musende AG, Eberding A, Wood CA, Adomat H, Fazli L, Hurtado-Coll A, Jia W, Bally MB, Tomlinson Guns ES (2012) A novel oral dosage formulation of the ginsenoside aglycone protopanaxadiol exhibits therapeutic activity against a hormone-insensitive model of prostate cancer. Anticancer Drugs 23: 543-552. http://dx.doi. org/10.1097/CAD.0b013e32835006f5.

Nag SA, Qin JJ, Wang W, Wang MH, Wang H, Zhang R (2012) Ginsenosides as anticancer agents: in vitro and in vivo activities, structure-activity relationships, and molecular mechanisms of action. Front Pharmacol 3: 25-38. http://dx.doi.org/10.3389\%2Ffphar.2012.00025.

Okita K, Li Q, Murakamio T, Takahashi M (1993) Anti-growth effects with components of Sho-saiko-to (TJ-9) on cultured human hepatoma cells. Eur J Cancer Prev. 2:169-175.

Osbourn AE (2003) Saponins in cereals. Phytochemistry 62: 1-4.

Pan XY, Guo H, Han J, Hao F, An Y, Xu Y, Xiaokaiti Y, Pan Y, Li X-J (2012) Ginsenoside Rg3 attenuates cell migration via inhibition of aquaporin 1 expression in PC-3M prostate cancer cells. Eur J Pharmacol 683: 27-34. http://dx.doi.org/10.1016/j.ejphar.2012.02.040.

Park SK, Hwang YS, Park KK, Park HJ, Seo JY, Chung WY (2009) Kalopanaxsaponin A inhibits PMA-induced invasion by reducing matrix metalloproteinase-9 via PI3K/Akt- and PKCdelta-mediated signaling in MCF-7 human breast cancer cells. Carcinogenesis 30: 1225-1233 http://dx.doi.org/10.1093/carcin/bgp111.

Patlolla JMR, Qian L, BiddickL, Zhang Y, Desai D, Amin S, Lightfoot S, Rao CV (2013) $\beta$-Escin inhibits NNK-induced lung adenocarcinoma and ALDH1A1and RhoA/Rock expression in A/J mice and growth of H460 human lung cancer cells. Cancer Prev Res 6: 11401149 http://dx.doi.org/10.1158/1940-6207.CAPR-13-0216.

Peng L, Zhou Y, Kong DY, Zhang WD (2010) Antitumor activities of dammarane triterpene from Bacopa monniera. Phytother Res. 24(6):864968. doi: 10.1002/ptr.3034.

Podolak I, Galanty A, Sobolewska D (2010) Saponins as cytotoxic agents: a review. Phytochem Rev 9: 425-474. http://dx.doi. org/10.1007\%2Fs11101-010-9183-z. 
Ruiz R, Hernández P (2014) Diet and cancer: risk factors and epidemiological evidence. Maturitas 77: 202-208. http://dx.doi. org/10.1016/j.maturitas.2013.11.010.

Qin H, Du X, Zhang Y, Wang R (2014) Platycodin D, a triterpenoid saponin from Platycodon grandiflorum, induces G2/M arrest and apoptosis in human hepatoma HepG2 cells by modulating the PI3K/Akt pathway. Tumour Biol 35: 1267-1274. http://dx.doi.org/10.1007/ s13277-013-1169-1.

Saxe GA, Major JM, Westerberg L, Khandrika S, Downs TM (2008) Biological mediators of effect of diet and stress reduction on prostate cancer. Integr Cancer Ther 7: 130-138. http://dx.doi. org/10.1177\%2F1534735408322849.

Schwingshackl L, Missbach B, König J, Hoffmann G (2015) Adherence to a Mediterranean diet and risk of diabetes: a systematic review and meta-analysis. Public Health Nutr 18: 1292-1299. http:// dx.doi.org/10.1017/S1368980014001542.

Scifo C, Milasi A, Guarnera A, Sinatra F, Renis M (2006) Resveratrol and propolis extract: an insight into the morphological and molecular changes induced in DU145 cells. Oncol Res 15: 409-421.

Shibata S (2001) Chemistry and cancer preventing activities of Ginseng saponins and some related compounds. J Korean Med Sci 16: 28-37.

da Silva SD, Morand GB, Alobaid FA, Hier MP, Mlynarek AM, Alaoui-Jamali MA, Kowalski LP (2014) Epithelial-mesenchymal transition (EMT) markers have prognostic impact in multiple primary oral squamous cell carcinoma. Clin Exp Metastasis 32: 55-63. http://dx.doi.org/10.1007/s10585-014-9690-1.

Sinha K, Das J, Pal PB, Sil PC (2013) Oxidative stress: the mitochondria-dependent and mitochondria-independent pathways of apoptosis. Arch Toxicol 87: 1157-1180 http://dx.doi.org/10.1007/s00204013-1034-4.

Son MK, Jung KH, Hong SW, Lee HS, Zheng HM, Choi MJ, Seo JH, Suh JK, Hong SS (2013) SB365, Pulsatilla saponin D suppresses the proliferation of human colon cancer cells and induces apoptosis by modulating the AKT/mTOR signalling pathway. Food Chem 136: 26-33. http://dx.doi.org/10.1016/j.foodchem.2012.07.096.

Steward WP, Brown K (2013) Cancer chemoprevention: a rapidly evolving field. Br J Cancer 109: 1-7. http://dx.doi.org/10.1038\%2Fbjc. 2013.280.

Tang X-P, Tang G-D, Fang C-Y, Liang Z-H, Zhang L-Y (2013) Effects of ginsenoside Rh2 on growth and migration of pancreatic cancer cells. World J Gastroenterol 19: 1582-1592. http://dx.doi. org/10.3748\%2Fwig.v19.i10.1582.

Thao NP, Luyen BT, Le Vien T, Tai BH, Le Dat D, Cuong NX, Nam NH, Van Kiem P, Van Minh C, Kim YH (2014) Triterpene saponins from the sea cucumber Stichopus chloronotus. Nat Prod Commun 9: 615-618.

Tin MM, Cho CH, Chan K, James AE, Ko JK (2007) Astragalus saponins induce growth inhibition and apoptosis in human colon cancer cells and tumor xenograft. Carcinogenesis 28: 1347-1355.

Ting H, Deep G, Agarwal C, Agarwal R (2014) The strategies to control prostate cancer by chemoprevention approaches. Mutation Res 760: 1-15.http://dx.doi.org/10.1016\%2Fj.mrfmmm.2013.12.003.

Vega FM, Ridely AJ (2008) Rho GTPases in cancer cell biology. FEBS Lett 582: 2093-2101. http://dx.doi.org/10.1016/j.febslet.2008.04.039

Wang Q, Zheng XL, Yang L, Shi F, Gao LB, Zhong YJ, Sun H, He F, Lin Y, Wang X (2010) Reactive oxygen species-mediated apoptosis contributes to chemosensitization effect of saikosaponins on cisplatin-induced cytotoxicity in cancer cells. J Exp Clin Cancer Res 29: 150-159. http://dx.doi.org/10.1186\%2F1756-9966-29-159.

Wang DM, Yu HS, Song JG, Xu YF, Liu CY, Jin FX (2011a) A novel ginsenosidase from an Aspergillus strain hydrolyzing 6-O-multi-glycosides of protopanaxatriol-type ginsenosides, named ginsenosidase type IV. J Microbiol Biotechnol 21: 1057-1063.

Wang Y, Deng L, Wang Y, Zhong H, Jiang X, Chen J (2011b) Natural plant extract tubeimoside I induces cytotoxicity via the mitochondrial pathway in human normal liver cells. Mol Med Rep 4: 713-718. doi: $10.3892 / \mathrm{mmr} .2011 .483$

Wang W, Zhang X, Qin JJ, Voruganti S, Nag SA, Wang MH, Wang H, Zhang R (2012) Natural product ginsenoside 25-OCH3PPD inhibits breast cancer growth and metastasis through down-regulating MDM2. PLoS One 7: 470-486. http://dx.doi. org/10.1371\%2Fjournal.pone.0041586.

Wang J, Liu Y, Zhao J, Zhang W, Pang X (2013a) Saponins extracted from by-product of Asparagus officinalis L. suppress tumour cell migration and invasion through targeting Rho GTPase signalling pathway. J Sci Food Agric 93: 1492-1498. DOI: 10.1002/jsfa.5922.

Wang T, Xuan X, Li M, Gao P, Zheng Y, Zang W1, Zhao G (2013b) Astragalus saponins affect proliferation, invasion and apoptosis of gastric cancer BGC-823 cells. Diagn Pathol 8: 179-189. http://dx. doi.org/10.1186\%2F1746-1596-8-179.

Wang P, Wang B, Chung S, Wu Y, Henning SM, Vadgama JV (2014) Increased chemopreventive effect by combining arctigenin, green tea polyphenol and curcumin in prostate and breast cancer cells. RSC Adv 4: 35242-35250.

Wei JH, Zheng YF, Li CY, Tang YP, Peng GP (2014) Bioactive constituents of oleanane-type triterpene saponins from the roots of Glycyrrbiza glabra. I Asian Nat Prod Res 8: 1-10.doi: 10.1080/10286020.2014.960857.

Welchman DP, Mathies LD, Ahringer J (2007) Similar requirements for CDC-42 and the PAR-3/PAR-6/PKC-3 complex in diverse cell types. Dev Biol 305: 347-357.

Wu J, Yang G, Zhu W, Wen W, Zhang F, Yuan J, An L(2012) Anti-atherosclerotic activity of platycodin D derived from roots of Platycodon grandiflorum in human endothelial cells. Biol Pharm Bull 35: 1216-1221. http://doi.org/10.1248/bpb.b-y110129.

Xia J, Chen J, Zhang Z, Song P, Tang W, Kokudo N (2014a) A map describing the association between effective components of traditional Chinese medicine and signaling pathways in cancer cells in vitro and in vivo. Drug Discov Ther 8: 139-153. http://doi.org/10.5582/ ddt.2014.01032.

Xia T, Wang,J-C, Xu W, Xu L-H, Lao C-H, Ye Q-X, Fang J-P (2014b) 20(S)-Ginsenoside Rh2 induces apoptosis in human leukaemia Reh cells through mitochondrial signaling pathways. Biol Pharm Bull 37: 248-254.

Xiao X, Yang M, Xiao J, Zou J, Huang Q, Yang K, Zhang B, Yang F, Liu S, Wang H, Bai P (2014) Paris Saponin II suppresses the growth of human ovarian cancer xenografts via modulating VEGF-mediated angiogenesis and tumor cell migration. Cancer Chemother Pharmacol 73: 807-818. doi: 10.1007/s00280-014-2408-x.

Xu MY, Lee SY, Kang SS, KimYS (2014a) Antitumor activity of jujuboside $\mathrm{B}$ and the underlying mechanism via induction of apoptosis and autophagy. J Nat Prod 77: 370-376. http://pubs.acs.org/doi/ full/10.1021/np401022g.

Xu N, Shi YN, Zhong X, Cao Y, Wang L, Jia TZ (2014b) A new saikogenin from the roots of Bupleurum bicaule. Chin I Nat Med 12: 305-308. http://dx.doi.org/10.1016/S1875-5364(14)60060-1.

Xue G, Zou X, Zhou J-Y, Sun W, Wu J, Xu J-L, Wang R-P (2013) Raddeanin A induces human gastric cancer cells apoptosis and inhibits their invasion in vitro. Biochem Biophys Res Commun 439: 196202. http://dx.doi.org/10.1016/j.bbrc.2013.08.060.

Yang X, Xiong X, Wang H, Wang J (2014) Protective effects of panax notoginseng saponins on cardiovascular diseases: a comprehensive overview of experimental studies. Evid Based Complement Alternat Med http://dx.doi.org/10.1155\%2F2014\%2F204840.

Yin Y, Chen W, Tang C, Ding H, Jang J, Weng M, Cai Y, Zou G (2011) NF- $x$ B, JNK and p53 pathways are involved in tubeimoside1 -induced apoptosis in HepG2 cells with oxidative stress and G/M cell cycle arrest. Food Chem Toxicol 12: 3046-3054. http://dx.doi. org/10.1016/j.fct.2011.10.001

Yoo JH, Kwon HC, Kim YJ, Park JH, Yang HO (2010) KG-135, enriched with selected ginsenosides, inhibits the proliferation of human prostate cancer cells in culture and inhibits xenograft growth in athymic mice. Cancer Lett 289: 99-110. http://dx.doi.org/10.1016/j. canlet.2009.08.008.

Yoon J-H, Choia Y-J, Chab S-W, Lee S-G (2012) Anti-metastatic effects of ginsenoside $\mathrm{Rd}$ via inactivation of MAPK signaling and induction of focal adhesion formation. Phytomedicine 19: 284-292. http://dx.doi.org/10.1016/j.phymed.2011.08.069.

Yu LJ, Ma RD, Wang YQ, Nishino H, Takayasu J, He WZ, Chang M, Zhen J, Liu WS, Fan SX (1992) Potent anti-tumorigenic effect of tubeimoside 1 isolated from the bulb of Bolbostemma paniculatum (Maxim) Franquet. Int J Cancer 50: 635-638.

Yu ML, Zhang CL, Yuan DD, Tong XH, Tao L (2012) Panax notoginseng saponins enhances the cytotoxicity of cisplatin via increasing gap junction intercellular communication. Biol Pharm Bull 8: 12301237. http://doi.org/10.1248/bpb.b110535.

Zhang Z, Gao J, Cai X, Zhao Y, Wang Y, Lu W, Gu Z, Zhang S, Cao $\mathrm{P}$ (2011) Escin sodium induces apoptosis of human acute leukemia Jurkat T cells. Phytother Res 25: 1747-1755. doi: 10.1002/ptr.3457

Zhang W, Luo JG, Zhang C, Kong LY (2013) Different apoptotic effects of triterpenoid saponin-rich Gypsophila oldhamiana root extract on human hepatoma SMMC-7721 and normal human hepatic L02 cells. Biol Pharm Bull 36: 1080-1087.

Zhang XM, Yang DP, Xie ZY, Xue X, Zhu LP, Wang DM, Zhao ZM (2014) A new triterpenoid saponin and an oligosaccharide isolated from the fruits of Sapindus mukorossi. Nat Prod Res 28: 1058-1064. http://dx.doi.org/10.1080/14786419.2014.905559

Zhang Z, Li Z, Wu X, Zhang CF, Calway T, He TC, Du W, Chen J, Wang CZ, Yuan CS (2015) TRAIL pathway is associated with inhibition of colon cancer by protopanaxadiol. I Pharmacol Sci 127: 83-91. http://dx.doi.org/10.1016/j.jphs.2014.11.003.

Zheng G-Y, Xin H-L, Li B, Xu Y-F, Yi T-J, Ling C-Q (2012) Total saponin from root of Actinidia Valvata Dunn prevents the metastasis of human hepatocellular carcinoma cells. Chin J Integr Med 18: 197-202. http://dx.doi.org/10.1007/s11655-012-1055-5. 